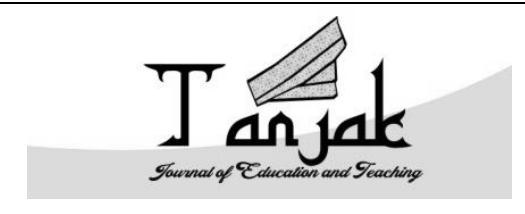
Tanjak: Journal of Education and Teaching
ISSN 2716-4098 (P) 2720-8966 (O)

Volume 1 Nomor 2, 2020

\title{
PEMAHAMAN NILAI-NILAI PANCASILA DALAM MEMPERKUAT KERUKUNAN UMAT
}

\author{
Doni Septian
}

STAIN Sultan Abdurrahman Kepulauan Riau, doni.septian@stainkepri.ac.id

DOI: https://doi.org/10.35961/tanjak.v1i2.147

\begin{abstract}
Abstrak
Pancasila merupakan aturan yang mengatur tata pola kehidupan bermasyarakat, berbangsa, berpemerintah dan bernegara serta kehidupan international. Tulisan ini mencoba menelaah dan memberikan pemahaman bidang, kedudukan dan fungsi serta nilai-nilai tersirat pancasila dalam memperkuat kerukunan umat di Indonesia. Dalam kajian ini diketahui bahwa Kerukunan umat dalam bingkai Negara Kesatuan Republik Indonesia tidak terlepas dari pentingnya pemahaman dan pengamalan bidang, kedudukan dan fungsi nilai-nilai pancasila, baik secara tersurat maupun secara tersirat. Jika nilai-nilai tersebut tidak dipahami secara mendalam, maka cita-cita dan tujuan kemenangan sebuah Negara Indonesia tidak akan terwujud. Pancasila telah menjadikan landasan dasar pijakan kita sebagai warganegara untuk saling bertaqwa kepada tuhan yang maha esa, hidup bersama tanpa diskriminasi, bersatu tanpa berpecah belah, bermusyawarah untuk mencapai mufakat dalam pengambilan keputusan serta bersikap dan berlaku adil bagi sesama. Bahkan dalam semua ajaran agama di Indonesia mengajarkan tentang nilai kebaikan, dan tidak ada satu ajaran agama manapun yang mengajarkan keburukan. Atas dasar inilah kesepakatan para pendiri bangsa kita menempatkan nilai ketuhanan pada sila pertama, dengan cita-cita nilai-nilai pancasila tersebut dijiwai, diilhami dan dirasakan bagi seluruh umat dan/atau warga Negara Indonesia. Di samping itu menjadi sumber etika dan moral dalam membentuk jati diri generasi penerus bangsa Indonesia.
\end{abstract}

Kata kunci: Pancasila; Kerukunan Umat

Tanjak: Jounal of Education and Teaching, Vol. 1, No. 2, 2020 


\begin{abstract}
Pancasila is a rule that governs the life of society, nation, government and state as well as international life. This paper tries to examine and provide an understanding of the field, position and function as well as the implied values of Pancasila in strengthening the harmony of the people in Indonesia. The language framework within the framework of the Unitary State of the Republic of Indonesia is inseparable from the understanding and practice of the field, position and configuration of Pancasila values, both explicitly and implicitly. If these values are not agreed upon in depth, then the goals and objectives of the victory of the Indonesian State will not be realized. Pancasila has formed our foundation as citizens to devote one another to an almighty God, to live together without conflict, unite without division, deliberate to reach consensus in work and support fairness for everyone. All in religion in Indonesia teaches about the value of goodness, and no religion teaches badness. It is on this basis that the agreement of our nations places the divine value in the first precepts, with the ideals of the Pancasila values that are inspired, inspired and accepted for all people and / or citizens of Indonesia. In addition it is a source of ethics and morals in designing the next generation of the Indonesian people..
\end{abstract}

Keywords: pancasila; community tolerance

\title{
Pendahuluan
}

Manusia di dalam kehidupannya sangat membutuhkan pendidikan, ilmu dan pengetahuan, sebagaimana ditegaskan Undang-Undang bahwa pendidikan merupakan usaha sadar dan terencana untuk mewujudkan suasana belajar dan pembelajaran, agar peserta didik secara aktif mengembangkan potensi dirinya untuk memiliki kekuatan spiritual keagamaan, pengendalian diri, kepribadian, kecerdasan, akhlak mulia serta keterampilan yang diperlukan dirinya, bermasyarakat, berbangsa dan bernegara.(UU_2003_No_20_-_Sistem_Pendidikan_Nasional.Pdf, n.d.). Artinya bahwa pendidikan merupakan usaha agar manusia dapat mengembangkan kemampuan yang dimiliki dirinya melalui proses pembelajaran dan atau cara lainnya yang dikenal serta diakui oleh masyarakat.

Tujuan Negara yang dirumuskan dalam pembukaan Undang-Undang Dasar 1945 yakni mencerdaskan kehidupan bangsa. Sejalan dengan itu dapat dimengerti bahwa pendidikan di Indonesia harus sesuai dengan ideologi falsafah negara. Beberapa pilar pendidikan yang menjadi rujukan dalam proses pembelajaran, yakni: learning to know (pembelajaran untuk tahu), learning to do (pembelajaran untuk berbuat), learning to be (pembelajaran untuk membangun jati diri), learning to live together (pembelajaran untuk hidup bersama, damai, aman dan secara harmonis). Dari ke-empat pilar tersebut, pilar yang menjadi rujukan utama, yakni bahwa pendidikan dimaksudkan dalam rangka pembelajaran untuk membangun kehidupan bersama atas dasar kesadaran akan realitas keragaman yang saling membutuhkan.

Lahirnya Undang-Undang tentang Pendidikan Tinggi, dimana setiap kurikulum pendidikan wajib memuat mata kuliah: pendidikan agama, pendidikan pancasila, pendidikan kewarganegara-an, dan bahasa Indonesia,(06. Undang-Undang Republik Indonesia Nomor 12 Tabun 2012 Tanggal10 Agustus 2012 Tentang Pendidikan Tinggi.Pdf, n.d.) serta sistem pendidikan tinggi di Indonesia harus berdasarkan Pancasila. Bahkan disebutkan bahwa pendidikan nasional berdasarkan Pancasila dan Undang-Undang Dasar Tahun 1945.(UU_2003_No_20_-_Sistem_Pendidikan_Nasional.Pdf, n.d.)

Pendidikan nasional berfungsi mengembangkan kemampuan membentuk etika, moral, peradaban serta watak dalam mencerdaskan kehidupan bangsa, agar berkembangnya potensi mahasiswa menjadi manusia yang bertaqwa kepada Tuhan Yang Maha Esa, berilmu, cakap, kreatif, mandiri, sehat, berakhlak mulia, serta menjadi warga negara yang moderat, demokratis dan amanah. Hal demikian 
menunjukkan bahwa Negara berkehendak agar pendidikan Pancasila di laksanakan dan wajib dimuat disetiap kurikulum pendidikan sebagai mata kuliah yang berdiri sendiri. Kemudian dalam membina pemahaman dan penghayatan mengenai ideologi bangsa Indonesia lebih dapat fokus. Artinya, nilai-nilai Pancasila ini di harapkan menjadi komitmen dalam membentuk jati diri dalam mengembangkan jiwa moderat, professional, menumbuhkan jiwa patriotik dan mempertebal rasa nasionalisme, meningkatkan semangat kebangsaan, kesetiakawanan sosial, kesadaran pada sejarah bangsa, dan sikap meng-hargai jasa pahlawan yang berorientasi kemasa depan. Salah satu usaha yang dilakukan adalah penanaman dan pemahaman nilai-nilai moral pancasila.

Pemahaman nilai-nilai pancasila ini sangat penting, karena berlakunya pendidikan pancasila di baik di sekolah maupun Perguruan Tinggi mengalami pasang surut, dimana kebijakan penyelenggaraan pendidikan pancasila tidak serta merta diimplementasikan, baik di sekolah Perguruan Tinggi Negeri maupun Perguruan Tinggi Swasta. Nilai-nilai Pancasila sebagai pandangan hidup bangsa itu sebenarnya sudah terwujud dalam kehidupan bermasyarakat sejak sebelum Pancasila sebagai dasar negara dirumuskan dalam satu sistem nilai.

Dahulu, wilayah-wilayah di Indonesia ini mempunyai beberapa nilai yang dipegang teguh oleh masyarakatnya, seperti: percaya kepada Tuhan, solidaritas/kesetiakawanan sosial, tenggang rasa, toleran, gotong royong, musyawarah dan lain sebagainya. Namun, saat sekarang ini munculnya sikap dekadensi moral dan etika yang terus melanda Indonesia yang ditandai dengan kehidupan politik para elit politik yang kering dari jiwa kenegarawanan, mulai mengabaikan budaya politik yang santun dan mulai mengendurnya ketaatan masyarakat terhadap norma-norma sosial yang hidup di masyarakat. Selain itu, penyalahgunaan obat-obatan yang melibatkan generasi muda dari berbagai lapisan, sehingga menggerus nilai-nilai etika dan moral anak bangsa.

Generasi muda hari ini belum bisa memaknai dan memahami secara utuh nilai-nilai tersirat yang terkandung di dalam pancasila tersebut, jika hal ini dipahami dengan baik, maka sikap seperti intoleransi, disintegrasi bangsa dan dekadensi moral yang terjadi pada hari ini tidak akan muncul. Fokus kajian ini hendak mengungkap dan menunjukkan bahwa betapa urgensinya pemahaman nilai-nilai pancasila dalam memperkuat kerukunan umat melalui metode observasi lapangan dengan pendekatan transformatif yang mengedepankan partisipasi aktif kelompok-kelompok dan masyarakat untuk mengupayakan terwujudnya perubahan sosial di masyarakat. Harus diakui bahwa pendekatan transformatif ini akan tercipta pemahaman antara akademisi, siswa, mahasiswa dan masyarakat untuk mewujudkan perubahan sosial secara berkelanjutan yang mengarahkan kepada perubahan dan penentu keberhasilan dari cita-cita dan tujuan Negara, yakni melindungi dan mencerdaskan kehidupan bangsa.

\section{PANCASILA DAN PROBLEMATIKA SAAT INI}

Dalam perjalanan sejarah bangsa, kini apa yang telah diperjuangkan para pendiri bangsa tengah menghadapi ujian dalam keberlangsungannya. Euphoria reformasi dan globalisasi yang syarat dengan semangat perubahan, telah mempengaruhi pola pikir, sikap dan tindak perilaku generasi penerus bangsa dalam menyikapi berbagai permasalahan kebangsaan. Pemahaman terkait nilai-nilai yang terkandung dalam Pancasila, semakin terdegradasi dan terkikis oleh derasnya nilai-nilai baru yang tidak sesuai dengan jati diri bangsa.(Memahami et al., n.d.)

Pancasila merupakan aturan yang mengatur tata kehidupan bermasyarakat, berbangsa, berpemerintah dan bernegara serta kehidupan international. Artinya nilai-nilai pancasila ini menjadi ide 
dan roh yang menjadi pedoman bagi masyarakat dan penyelenggara Negara dalam hal ini Pemerintah dalam melaksanakan tugas dan fungsinya, serta menjadi pandangan dan membentuk jati diri di dalam kehidupan bermasyarakat, berbangsa dan bernegara.

Selama ini masyarakat pada umumnya dan terkhusus mahasiswa berdasarkan pengamatan yang penulis lakukan, belum sampai ke arah sana, jika ditanya sejauhmana mereka memahami nilai-nilai pancasila, dan rata-rata dari mereka hanya menjawab 5 (lima) sila yang tersurat pada teks pancasila saja, bahkan ada juga yang tak hafal dari teks Pancasila tersebut. Melihat realitas semacam itu, tidak mengherankan kalau generasi muda hari ini buta akan jati diri bangsa yang bersumber pada Pancasila. Hal ini yang perlu dipahami bahwa nilai-nilai pancasila itu tidak hanya yang tersurat pada teks itu saja, namun ada nilai-nilai yang tersirat di balik 5 (lima) nilai tersurat tersebut. Ini sangat urgen, karena jika nilai-nilai ini sudah di pahami secara utuh dan mendalam, maka jati diri generasi bangsa akan kokoh dalam menjalankan kehidupan bersama yang penuh dengan keberagaman dan perbedaan. Namun sebaliknya, jika nilai-nilai tersebut tidak dipahami secara utuh dan mendalam, maka disitulah akan menimbulkan rusaknya moralitas bangsa.

Indonesia terdiri dari berbagai pulau, bahasa, agama, ras, suku dan bangsa yang merupakan kekayaan yang dimiliki dan terbingkai dalam kebhinekaan tunggal ika sebagai bagian dari rahmat allah yang maha kuasa. Pancasila harus menjadi satu-satunya ide dasar Negara Republik Indonesia yang harus dipahami kembali makna nilai-nilai yang tersirat atau terkandung di dalamnya. Karena secara aplikasi di lapangan hari ini, banyak paham-paham ideologi bangsa lain yang menyerbu generasi bangsa Indonesia, sehingga menimbulkan misleading atau perilaku dan tindakan yang tidak sesuai dengan kepribadian dan karakter bangsa Indonesia itu sendiri.

Bahkan akhir-akhir ini timbul polemik isu-isu yang hangat diperbincangkan di media, dimana polemik terkait adanya usulan Rancangan Undang-Undang Haluan Ideologi Pancasila (RUU HIP). Dalam polemik tersebut, banyak pihak yang saling memberikan argumentasi terkait RUU HIP ini, ada yang pro dan ada juga yang kontra. Di satu sisi, ada pihak yang menganggap bahwa RUU ini merupakan Undang-Undang dan/atau payung hukum untuk Badan Pembinaan Ideologi Pancasila (BPIP) dalam melaksanakan kinerjanya. Kemudian dari sisi lainnya, ada pihak menganggap RUU HIP ini berpretensi kembali berubahnya pancasila yang sudah final di undangkan pada tanggal 18 agustus 1945 menjadi trisila (sosio-nasionalisme, sosio-demokrasi dan ketuhanan yang berkebudayaan) yang dikristalisasikan menjadi ekasila (gotong royong) sebagaimana yang disampaikan pada pidato bung karno pada tanggal 1 juni 1945. Hal tersebut menimbulkan polemik anggapan beberapa pihak bahwa RUU HIP ini ingin merubah dasar Negara Indonesia dengan mengesampingkan nilai ketuhanan yang ada di sila pertama. Menurut penulis, RUU HIP tersebut "semacam satu dapur dua kemasan". Dimana, jika RUU HIP ini diundangkan, cacat krusial dari RUU itu bukan terletak pada tidak masuknya TAP MPRS NO: XXV/1966 mengenai Komunisme dan PKI dalam konsideran, melainkan karena RUU ini berpretensi menjadi Undang-Undang Dasar. Sebagai dasar negara, satu-satunya "Undang-Undang" yang berhak mengatur bagaimana Pancasila diinstitusikan ke dalam sistem hukum, pemerintahan, ekonomi dan kemasyarakatan hanyalah "Undang-Undang Dasar 1945", bukan Undang-Undang lainnya.

Sebenarnya RUU HIP tersebut tidak ada gunanya bagi masyarakat Indonesia, karena jika kita melihat kembali kepada sejarah, bahwa pancasila yang lahir pada tanggal 18 agustus 1945 itu sudah final, sebagai falsafah yang menjiwai bangsa dalam penyelenggaraan Negara, tidak boleh diganggu gugat lagi. Kemudian, justru sebaliknya RUU ini menegaskan bahwa pancasila ini milik dan mengguntungkan 
pihak pemerintah, dimana tafsir di RUU HIP tersebut mengatakan bahwa "Presiden memegang kekuasaan haluan ideologi pancasila", ini sangat berbahaya dan bisa menjadikan system pemerintahan Indonesia yang otoriter, sehingga menimbulkan anggapan siapa yang tidak sejalan dengan Presiden dianggap tidak pancasilais, radikal, makar dan sebagainya seperti era orde lama dan orde baru, dan bisa kemungkinan pancasila menjadi alat pembeda, alat penggebuk, alat memukul namun bukan alat untuk merangkul.

Dalam hal ini, Pancasila tidak boleh di klaim oleh pihak manapun, karna pancasila milik seluruh rakyat Indonesia bukan perorangan maupun kelompok tertentu. Pancasila harus menjadi dasar ideology, landasan berpikir yang bersifat terbuka, tidak boleh tertutup. Sebenarnya nilainya sudah ada sejak dari dulu, namun tidak dijalankan dengan sebaiknya. Secara hirarkis pancasila di atas Undang-Undang Dasar 1945, dan tidak masuk akal jika pancasila di degradasikan di bawah Undang-Undang Dasar 1945. Pada intinya polemik ini tidak terjadi jika para pihak bersepakat bahwa pancasila sudah final sebagaimana yang ditetapkan pada tanggal 18 agustus 1945.

Berdasarkan penjelasan tersebut di atas, dalam tulisan ini penulis tidak membahas secara jauh terkait problematika atau polemik pancasila hari ini, namun penulis ingin menjabarkan mengenai nilainilai tersirat yang terkandung di dalam pancasila. Sebelum penulis menjabarkan nilai-nilai pancasila, alangkah lebih baik nya kita pahami terlebih dahulu bidang, kedudukan dan fungsi pancasila.

\section{BIDANG, KEDUDUKAN DAN FUNGSI PANCASILA}

Adapun bidang, kedudukan dan fungsi pancasila sebagaimana yang dijelaskan oleh Prof. Suteki terbagi menjadi 4 (empat) bagian, yakni: (Prof. Suteki, Dosen Matkul Pancasila Yang Dicopot Dari Jabatan Kerena Berbeda Pendapat, 2020)

1. Bidang Kehidupan Bermasyarakat

Dalam kehidupan bermasyarakat kedudukan pancasila sebagai way of life, yang sebagaimana fungsinya mengatur tata kehidupan masyarakat sehari-hari, misalnya: dalam bertetangga atau dalam komunitaskomunitas tertentu yang perlu dibingkai dengan nilai-nilai pancasila.

2. Bidang Kehidupan Berbangsa (Nation)

Pada bidang kedua ini kedudukan pancasila sebagai ideology bangsa, yang sebagaimana fungsinya untuk mempersatukan keragaman yang ada dan memperkuat kerukunan umat.

3. Bidang Kehidupan Bernegara dan Berpemerintah

Pada bidang yang ketiga ini kedudukan pancasila sebagai dasar Negara, jika dikaitkan dengan Undang-Undang Nomor 12 Tahun 2011 Tentang Pembentukan Peraturan Perundang-Undangan, yang sebagaimana fungsinya untuk mengatur tata kehidupan bernegara dan berpemerintah yang mana pancasila sebagai sumber dari segala sumber hokum di Indonesia.

4. Bidang Mondial atau Kehidupan International

Dalam bidang yang keempat ini kedudukan pancasila sebagai the margin of appreciation, yang fungsinya sebagai filter nilai-nilai budaya asing yang masuk ke Indonesia ataupun nilai budaya lokal, apakah nilai asing atau lokal sesuai atau tidak dengan karakter pancasila.

Berdasarkan penjelasan tersebut, artinya pancasila tidak boleh di distorsi atau direduksi hanya menjadi ideology pancasila, harus merangkul dari keempat bidang, kedudukan dan fungsi pancasila, karena pancasila tidak bisa hanya menempatkan sebagai ideology saja, hal ini bisa kebablasan dan salah besar, sama dengan terbentuknya Badan Pembinaan Ideologi Pancasila ini bisa melunturkan 
nilai keluhuran pancasila itu sendiri, dikhawatirkan menjadi alat penggebuk bagi masyarakat yang tidak sependapat dengan Pemerintah.

Dengan demikian, dalam hal ini sebelum kita memaknai nilai-nilai pancasila, kita harus betul-betul terlebih dahulu memahami bidang, kedudukan dan fungsi pancasila dan kita tidak boleh mereduksi apalagi mendistorsi nilai-nilai pancasila.

\section{MAKNA NILAI-NILAI TERSIRAT DALAM PANCASILA}

Pemahaman merupakan aspek intelektual yang berkaitan dengan apa yang diketahui oleh manusia. Pemahaman merupakan sebuah proses yang terjadi secara tiba-tiba tentang keterkaitan yang terjadi yang terjadi dalam keterkaitan yang terjadi dalam keseluruhan. Jadi pemahaman merupakan suatu proses persepsi atas keterhubungan antara beberapa faktor yang saling mengikat secara menyeluruh dan persepsi di artikan sebagai penafsiran stimulus yang telah ada dalam otak.

Berdasarkan pendapat tersebut di atas, maka dapat ditarik suatu konsep pengertian bahwa pemahaman adalah mengerti atau dapat menjawab pertanyaan tentang apa, mengapa, sebab apa, bagaimana dan untuk apa. Sedangkan nilai merupakan esensi yang melekat pada sesuatu yang sangat berarti bagi kehidupan manusia, khususnya mengenai kebaikan dan tindak kebaikan suatu hal, Nilai artinya sifat-sifat atau hal-hal yang penting atau berguna bagi kemanusiaan.

Pancasila merupakan pandangan dan falsafah hidup bangsa Indonesia yang syarat dengan nilainilai etika dan moral yang luhur, memiliki karakteristik negara kekeluargaan yang mengakui hak-hak setiap manusia, mengutamakan kepentingan yang bersifat Nasional di atas kepentingan pribadi. Nilai sosial masyarakat Indonesia bersifat paguyuban yang dapat membentuk sikap saling menghormati dan menghargai.(MD et al., 2012). Pancasila memiliki peranan penting dalam kehidupan manusia, menanamkan nilai-nilai Pancasila sehingga terbentuk manusia yang berkepribadian utuh. Karena itu penerapan nilai-nilai Pancasila tidak dapat diabaikan dan harus menjadi kebutuhan pokok dalam pembelajaran.

\section{Nilai Ketuhanan Yang Maha Esa}

Sila Ketuhanan Yang Maha Esa merupakan "roh" sekaligus dasar dari keempat sila lainnya. Ketuhanan Yang Maha Esa bermakna bahwa Bangsa Indonesia adalah Negara yang mono-theisme percaya terhadap Tuhan yang satu bukan sebaliknya. Dengan kata lain, negara Indonesia berlandaskan agama. Pancasila dengan sila pertamanya, adalah sebuah falsafah yang sesuai dan bersahabat dengan agama. Oleh karenanya, sudah seharusnya sebagai Insan yang beriman dan bertakwa kepada Allah dengan mendirikan perintahnya guna meningkatkan keshalehan kita. Kita sebagai bangsa Indonesia sudah sepatutnya menyadari realitas kemajemukan Indonesia sebagai sebuah berkah dari Allah, yang perlu dikembangkan dan dilestarikan.

Keberagaman dan multikultural semestinya tidak bersifat hierarkis, melainkan egaliter, dan oleh karena itu berimplikasi pada nilai etis toleransi. Sebagai umat beragama yang beriman dan bertakwa kepada Allah, sudah semestinya kita menanamkan nilai-nilai kebenaran, kebaikan, kejujuran, dan kemuliaan dalam diri, sehingga meningkatkan moral bangsa dengan Percaya \& taqwa kepada Tuhan YME, Saling menghargai antar pemeluk agama dan kepercayaan, Memiliki kebebasan menjalankan ajaran agama dan kepercayaan, Tidak memaksakan suatu agama atau kepercayaan terhadap orang lain dan Mencintai mahluk semua Tuhan. 


\section{Nilai Kemanusiaan Yang Adil dan Beradab}

Nilai yang terkandung dari sila kedua pancasila adalah nilai kemanusiaan. Kemanusiaan yang dimaksud adalah manusia yang adil dan beradab, menjunjung tinggi nilai-nilai keadilan dan martabat manusia sebagai makhluk Tuhan, yang diwujudkan dalam semangat saling menghargai, toleran, yang dalam perilaku sehari-hari didasarkan pada nilai-nilai moral yang tinggi, serta untuk kepentingan bersama. Hal ini diwujudkan dengan mengakui keberadaan manusia sebagai makhluk Tuhan yang paling mulia, mengakui harkat dan martabat manusia, menjunjung tinggi nilai kemanusiaan, memperlakukan manusia secara adil dan beradab, mengembangkan sikap tenggang rasa terhadap orang lain dan mendorong kemerdekaan sebagai hak segala bangsa.

Dengan mengimplementasikan sila kedua ini diharapkan bahwa permaslahan yang dialami bangsa saat ini seperti tidak adanya toleransi, konflik antar golongan, pengangguran, kemiskinan, mafia kasus, korupsi, diskriminasi dan kesenjangan sosial, tindakan kekerasan, baik secara vertikal maupun horizontal, dapat teratasi.

\section{Nilai Persatuan Indonesia}

Negara Indonesia adalah Negara yang kaya akan keberagaman suku, agama, bahasa, budaya, dan ras. Namun dengan terbentuknya Negara Kesatuan Republik Indonesia, dimulailah kesepaka-tan dan komitmen bersama untuk terus membentengi keberagaman itu untuk mewujudkan Indonesia yang maju, adil, dan sejahtera. Itulah makna yang terkandung dari sila persatuan Indonesia. Sesuai dengan konstitusi tujuan negara ialah berkewajiban memberikan perlindungan kepada segenap tumpah darah Indonesia dan seluruh isinya dengan semangat persatuan tersebut.

Nilai sila ketiga ini dapat diwujudkan dengan menghargai kebhinekaan, memiliki rasa cinta tanah air dan bangsa, rela berkorban untuk kepentingan bangsa dan negara, mengutamakan persatuan, kesatuan, kepentingan, dan keselamatan bangsa dan negara, serta membina persatuan dan kesatuan bangsa.

Perlakuan yang sama pada seluruh warga dimanapun berada haruslah dilakukan oleh pemerintah tanpa memandang latar belakang suku, ras, budaya, maupun agamanya. Warga negara dalam semangat kebersamaan seharusnya melakukan tindakan yang tetap menunjukkan sikap dan perbuatan yang NKRI untuk kebahagiaan dan kemajuan bersama. Semangat persatuan inilah yang harus terus dijaga agar NKRI tetap eksis, dan dapat menjadi kuat karena terbangun dari jalinan keberagaman yang harmonis.

\section{Nilai Kerakyatan Yang Dipimpin Oleh Hikmat Kebijaksanaan dalam Permusya- waratan/Perwakilan}

Undang-Undang Dasar 1945 mengamanatkan untuk newujudkan negara yang demokratis, yang mana kedaulatan diserahkan sepenuhnya kepada rakyat. Nilai yang terkandung Sila keempat pancasila ini adalah pedoman berdemokrasi Indonesia. Namun bagaimana cara mengimplemen-tasikan demokrasi Indonesia masih dalam tahap pencarian identitas. Sejak merdeka, Indonesia telah melalui beberapa tahapan demokrasi, yaitu demokrasi masa revolusi, demokrasi parlementer, demokrasi terpimpin, demokrasi era orde baru dan demokrasi era reformasi. Bagaimana dasar demokrasi khas Indonesia, dikemukakan oleh Soekarno di depan sidang BPUPKI 1 Juni 1945. Soekarno berpidato, 
"Dasar itu ialah dasar mufakat, dasar perwakilan, dasar permusyawaratan. Negara Indonesia bukan satu negara untuk satu orang, bukan negara untuk satu golongan, walaupun golongan kaya. Tetapi kita mendirikan negara, satu untuk semua, satu buat semua, semua buat satu. Saya yakin bahwa syarat yang mutlak untuk kuatnya negara Indonesia ialah per-musyawaratan perwakilan"(Memahami et al., n.d.).

Nilai sila keempat ini dapat dilihat dan pahami dari keedaulatan negara ada di tangan rakyat, manusia Indonesia sebagai warga masyarakat dan warga negara mempunyai kedudukan, hak, dan kewajiban yang sama, musyawarah untuk mencapai mufakat dengan semangat kekeluargaan dan mengutamakan musyawarah dalam setiap pengambil keputusan.

Dengan kata lain demokrasi Indonesia adalah musyawarah mufakat. Namun, dalam kenyataannya, pelaksanaan praktik politik di Indonesia belum mengutamakan permusyawaratan untuk mufakat. Sebaliknya, tren baru yang berkembang pada saat ini mengarah pada demokrasi transaksional. Uang menjadi kekuatan dalam menguasai politik, kelompok yang memiliki uang yang berlimpah yang akan menguasai dan memenangkan perpolitikan. Inilah yang pada akhirnya dikhawatirkan akan memberikan Negara kepada kendali suatu kelompok tertentu Kondisi ini akan diperparah apabila demokrasi ekonomi, dan sosial tidak dilakukan, dan pemimpin yang visioner tidak dimiliki. Oleh karena itu, penting untuk mengkaji ulang gagasan demokrasi sesungguhnya sesuai dengan amanat sila ke empat pancasila ini.

\section{Nilai Keadilan Sosial Bagi Seluruh Rakyat Indonesia}

Nilai sila keadilan sosial mengandung makna bahwa setiap warga negara diperlakukan sama tanpa adanya perbedaan suku, ras, agama, bahasa, kaya dan miskin, maupun jabatan. Semua warga negara harus diperlakukan adil oleh negara. Perwujudan dari sila keadilan sosial ini dapat berupa penegakan mukum dengan asas keadilan bukan keuangan dan jabatan, tidak ada tekanan baik fisik maupun mental terhadap rakyat, mendapatkan kehidupan yang sejahtera atau terbebas dari kemiskinan, dan kebodohan, serta dari tekanan pihak asing. Pemerintah berpihak kepada rakyat yang harus dibela, bukan kepada golongan tertentu yang mempunyai kepentingan. Itulah prinsip keadilan yang terkandung dalam sila ke-lima. Namun sesungguhnya prinsip keadilan sosial bagi seluruh rakyat Indonesia menjadi anak tangga pertama yang harus dipijak dalam kehidupan berbangsa dan bernegara. Keadilan dalam konteks aturan, kebijakan, tindakan, dan perlakuan yang adil terhadap rakyatnya dapat membuat masyarakat leluasa bermusyawarah dan bermufakat mencari solusi persoalan.

Nilai sila kelima ini, dapat dilakukan dengan mewujudkan rasa dan sikap keadilan dalam kehidupan bermasyarakat dan bernegara, melindungi seluruh rakyat Indonesia dari berbagai masalah sosial, bersikap adil dan suka memberi pertolongan, mewujudkan kesejahteraan bagi setiap warga negara dan inta kemajuan dan pembangunan bangsa, baik material maupun spiritual.

Tegaknya keadilan membuat bangsa akan lebih mudah dalam menyatukan kekuatan untuk dapat mewujudkan kemakmurannya yang bermartabat. Keadilan juga akan mempertebal rasa kemanusiaan dan saling mencintai sesama ciptaan Tuhan. Akhirnya keadilan dapat membuat setiap orang tenang beribadah tanpa harus merasa terancam oleh kelompok lain yang berbeda keyakinan.

Dengan demikian, berdasarkan kelima makna nilai tersirat dalam pancasila di atas, dapat dipahami bahwa perlunya penguatan pemahaman nilai-nilai pancasila, agar tidak mudah ter-pengaruh oleh paham nilai-nilai budaya asing atau lokal yang mendoktrin yang membuat kita sebagai generasi bangsa terserabut dari akar jati diri bangsa Indonesia. Jika kita sudah memahami nilai-nilai pancasila 
dengan baik, maka polemik-polemik atau problematika yang terjadi seperti hari ini bisa terminimalisir dan hilang dengan sendirinya, sehingga kerukunan umat akan terwujud.

\section{PANCASILA MEMPERKUAT KERUKUNAN UMAT BERAGAMA}

Keberhasilan pengelolaan keberagaman, kemultikulturan dan kemajemukan masyarakat tidak bisa di lepaskan dari peran strategis kedudukan pancasila sebagai ideologi pemersatu bangsa. Menurut Shadily menjelaskan bahwa "filsafat Pancasila adalah dasar ampuh untuk menyuburkan kerjasama antara suku dan golongan-golongan yang ada di Indonesia menuju kesatuan dan harmoni”. Pancasila telah menjadi salah satu faktor penting yang mengintegrasikan masyarakat dengan segala kekhasan perbedaannya.(Timur et al., 2017) Jika meminjam istilah Nengah Bawa Atmadja "Pancasila merupakan rumah bagi kemultikulturan", artinya bahwa Pancasila sebagai suatu pernyataan bangsa yang memuat kesepakatan masyarakat tentang pengakuan adanya pluralitas atau multikulturalitas. Gagasan tersebut sejalan dengan penjelasan Yewangoe yang menyatakan bahwa "Pancasila adalah rumah bersama, yang di dalamnya kita semua, apapun agama dan sukunya, tinggal bersama-sama”.(Timur et al., 2017)

Berkenaan dengan itu, maka dalam pandangan Falsafah dan Ideologi Pancasila semua warga negara sama kedudukannya, sama kewajiban dan sama haknya, tanpa diskriminasi, tanpa membedabedakan agama, suku, ras, etnik, mayoritas dan minoritas. Wujud nyata sumbangan ideologi Pancasila dalam membina hubungan harmonis antar umat beragama dapat diketahui dari penjabaran makna Sila pertama, yakni Ketuhanan Yang Maha Esa, dalam kehidupan sehari-hari.

Menurut Soekarno sila ini dimplementasikan dengan cara bangsa Indonesia harus berjuang membangun bangsa yang percaya kepada Tuhan Yang Maha Esa. Ketuhanan Yang Maha Esa dapat menjadi pengikat batin bangsa Indonesia untuk bersatu dengan kokoh, sehingga sila ini menjadi meja statis bagi rakyat Indonesia dan menjadi leitstar dinamis, yaitu menjadi bintang penunjuk arah atau bintang pembimbing bangsa Indonesia untuk membangun suatu bangsa yang berketuhanan Yang Maha Esa.

\section{Kerukunan Umat dalam Perspektif Agama Islam}

Kerukunan antar umat beragama tidak dapat dilepaskan dari visi agama Islam tentang toleransi. Toleransi atau penghargaan terhadap perbedaan dalam beragama secara substansial menyatu dengan agama Islam. Gagasan tersebut dapat dicermati dalam kutipan sebagai berikut. "Berangkat dari diktum "tidak ada paksaan dalam beragama" dan "Nabi memang melarang memaksa pihak lain untuk beriman" maka jalan yang terbaik dan sah bagi seorang Muslim dalam kehidupan bermasyarakat adalah mengembangkan kultur tolerensi. Karena Al-Qur'an menguat-kan adanya eksistensi keberbagaian suku, bangsa, agama, bahasa, dan sejarah, semuanya itu hanya mungkin hidup dalam harmonis, aman, dan damai, jika di sana kultur lapang dada dijadikan perekat utama. Sikap lapang dada harus muncul dari kepercayaan diri yang tinggi, bukan dari suasana batin yang tidak berdaya. Mereka yang percaya diri tidak mungkin gampang melihat perbedaan, betapapun tajamnya, asal senantiasa dicarikan solusi bersama untuk mengatasinya" Maarif dalam (Timur et al., 2017).

Berangkat dari pendapat di atas dapat diambil sebuah analisa bahwa agama Islam sesungguhnya sangat menghargai umat beragama lain. Dengan kata lain bagaimana masyarakat muslim sangat memiliki jiwa toleransi yang tinggi terhadap masyarakat di luar muslim. Tidak hanya sampai pada toleransi dan simpati tetapi sudah mencapai sikap empati. Hal ini dapat dilihat dari bentuk silahturahmi yang dilakukan antar umat beragama. Silahturahmi ini tidak hanya terjadi interumat beragama, tetapi 
antarumat beragama. Misalnya bagaimana umat islam ikut mengaman-kan hari raya Nyepi umat Hindu, dan begitu juga sebaliknya bagaimana umat Hindu juga melibatkan diri dari hari-hari raya keagamaan umat Islam dan umat agama lain. Di dalam ajaran agama Islam menganjurkan manusia untuk saling bekerjasama dan tolong menolong (ta'awun) dengan sesama manusia dalam hal kebaikan, dalam kehidupan sosial kemasyarakatan dengan siapa saja tanpa terbatas oleh ras, suku, agama, dan bangsa.(Timur et al., 2017)

Lebih lanjut dijelaskan bahwa hubungan sosial dalam ajaran agama Islam dapat terjadi dalam lingkungan intern maupun lingkungan ekstern. Dalam lingkungan intern atau antar pemeluk agama Islam sendiri dapat dilihat pada beberapa konsep seperti ukbuwah (persaudaraan) dan jamaah. Ukhuwah sendiri dalam ajaran islam terdiri dari ukhuwah ubudiyah (saudara sekemakhlukan dan kesetundukan kepada allah), ukhuwah insaniyah (saudara dengan seluruh manusia karena berasal dari ayah dan ibu yang sama; Adam dan Hawa), ukhuwah wathaniah wannasab (persaudaraan dalam keturunan dan kebangsaan), ukbuwah fid din al islam (persaudaraan sesama muslim).(Timur et al., 2017)

Selain mengajarkan bagaimana menjalin hubungan yang baik dengan sesama muslim, agama Islam juga mengajarkan bagaimana mengajarkan bagaimana menjalin hubungan yang harmoni dengan umat agama lain. Hal ini sesuai dengan sebagaimana diungkapkan dalam Alquran QS.49:13: "Wabai seluruh umata manusia, sesunggubnya kami telah menciptakan kamu dari seorang laki-laki dan seorang perempuan dan kami menjadikan kamu berbangsa-bangsa dan bersuku-suku agar kamu saling mengenal. Sesunggubnya yang paling mulia diantara kamu di sisi Allah adalah yang paling bertakwa. Sesungguhnya Allah maha mengetahui dan mengenal ".

Kutipan ayat alquran di atas menunjukkan bahwa agama Islam bersifat bolistik dalam artian tidak membedakan antara agama, ras, suku, dan bangsa. Bahwa sesunguhnya Islam mengajarkan toleransi kepada setiap umat manusia yang ada di muka bumi ini. Ide tentang kemajemukan ini merupakan prinsip dasar dalam Islam. Islam adalah agama yang sangat toleran dan menghargai pendapat sesama umat Islam (intern umat Islam), yang didasari atas ukhuwah Islamiyah. Hal ini sesuai dengan apa yang diisyaratkan al-Qur'an dalam surat al-Hujurat/49:11 yang berbunyi: 'Hai orang-orang yang beriman, janganlah suatu kaum mengolokolokkan kaum yang lain (karena) boleh jadi mereka (yang diperolokolokan) lebih baik dari mereka (yang memperolok-olokekan)

Dalam surat al-Maidah/5:48 dijelaskan juga mengenai keragaman dan toleransi yang berbunyi "Dan sekiranya Allah menghendaki, niscaya kamu dijadikan-Nya satu umat (saja), tetapi Allah hendak menguji kamu terbadap pemberian-Nya kepadamu, maka berlombalombalah dalam berbuat kebajikan. Hanya kepada Allahlah kamu kembali semuanya, lalu diberitakan-Nya kepadamu apa yang telah perselisibkan itu."

Dalam Islam tidak dibenarkan memaksakan kebenaran kepada umat agama lain (QS. alBaqarah: 256). Ajaran Islam melarang umatnya mempengaruhi siapapun untuk masuk Islam, apalagi dalam bentuk tekanan-tekanan sosial dan politik. Umar bin Khattab sering mempengaruhi budaknya, Astiq non-Islam untuk menerima Islam. Akan tetapi ketika budaknya menolak, Umar hanya dapat berucap: la ikraha fi al-din (tidak ada paksaan dalam agama Islam).

\section{Kerukunan Umat Dalam Perspektif Agama Hindu}

Potret kerukunan antarumat beragama jika dilihat dari perspektif ajaran agama Hindu, misalnya terihat pada ajaran tat twam asi dan abimsa (nirkekerasan). Tat twam asi menekankan pada persaudaraan holistik, dengan asumsi bahwa secara substansial manusia adalah bersaudara secara ketubuhan (bahan 
baku Panca Mahabuta) dan di dalamnya terdapat atman sebagai percikan Tuhan (Brahman). Ahimsa adalah larangan untuk melakukan kekerasan atau himsa dalam pikiran, ucapan dan tindakan. (Timur et al., 2017) Kedua konsep di atas melandasi kerukunan dan tolerasi antarumat beragama karena tat twam asi yang menekankan pada gagasan kita adalah bersaudara, menimbulkan implikasi, bahwa abimsa menjadi wajib diterapkan pada semua manusia, tanpa membedakan agama, etnisitas, kelas sosial, dan lain-lain. Jika seseorang melakukan himsa pada orang lain, berarti dia melakukan kekerasan terhadap dirinya sendiri. Sebab, kita adalah bagian dari mereka sehingga secara substansial kita adalah mereka, dilihat dari segi petampakan ketubuhan bisa berbeda, namun secara substansial kita adalah sama sehingga pengembangan hubungan berkesaudaraan wajib hukumnya.

Latar belakang kerukunan dan toleransi berakar pula pada ideologi Tri Hita Karana. Ideologi Tri Hita Karana merupakan abstraksi empirik dalam konteks hubungan manusia dengan alam, interaksi antar sesama manusia, dan interaksi antara manusia dengan kekuatan adikodrati (Tuhan). Kondisi ini mengakibatkan manusia mendapatkan pemahaman, bahwa hubungan harmonis antara tiga komponen, yaitu manusia, alam, dan kekuatan adikodrati meupakan persyaratan penting bagi pemenuhan kebutuhan dasar manusia. Gagasan inilah yang melahirkan ideology Tri Hita Karana yang menggariskan, bahwa kesejahteraan hidup manusia tergantung pada sejauh mana manusia bisa berhubungan harmonis dengan alam yang disebut Palemahan, berhubungan harmonis dengan sesama manusia yang disebut Pawongan, dan berhubungan harmonis dengan kekuatan adikodrati (Tuhan) yang disebut Parabyangan. Pawongan tidak hanya menyangkut hubungan harmonis dengan sesama orang Hindu, tetapi bisa pula dimplementasikan dengan orang non-Hindu atau orang Islam, Buddha, Kristen yang hidup pada ruang yang sama.

Gagasan tersebut diperkuat lagi dengan dalil desa (keruangan/ekosistem), kala (kewaktuan/ kesejarahan), dan patra (kreativitas manusia menjawab kondisi yang mereka hadapi). Dalil desa, kala, patra tidak bisa dilepaskan dengan ideologi Tri Hita Karana. Keberlakukan dalil desa, kala, patra mengakibatkan manusia mengakui adanya relativisme kebudayaan dalam konteks aplikasi ideologi Tri Hita Karana. Jika suatu desa (kampong, bajar, dusun dalam suatu desa) memiliki kebudayaan yang berbeda, karena agama yang dianutnya berbeda, misalnya ada yang menganut agama Islam, Kristen, Buddha maka perbedaan tersebut harus dihormati, tidak saja karena sesuai dengan asas desa, kala, patra, tetapi juga untuk mewujudkan sasaran ideologi Tri Hita Karana, yakni menciptakan masyarakat yang harmonis.

\section{Kerukunan Umat Dalam Perspektif Agama Kristen}

Dalam ajaran agama Kristen juga ditemui konsep tentang kerukunan, hal ini sebagaimana tercantum dalam Deklarasi Konsili Vatikan II tentang sikap, Gereja terhadap, agama-agama lain didasarkan pada asal kisah rasul-rasul 17:26 sebagai berikut: "Adapun segala bangsa itu merupa-kan satu masyarakat dan asalnya pun satu juga, karena Tuhan menjadikan seluruh bangsa manusia untuk menghuni seluruh bumi." Dalam bagian lain dari Mukadimah Deklarasi tersebut di sebutkan: "Dalam zaman kita ini, di mana bangsa, manusia makin hari makin erat bersatu, hubungan antara bangsa menjadi kokoh, gereja lebih seksama mempertimbangkan bagaimana hubungannya dengan agamaagama Kristen lain. Karena tugasnya memelihara persatuan dan perdamaian di antara manusia dan juga di antara para bangsa, maka di dalam deklarasi ini gereja mempertimbangkan secara istimewa apakah kesamaan manusia dan apa yang menarik mereka untuk hidup berkawan."(Timur et al., 2017) 
Deklarasi konsili Vatikan II di atas berpegang teguh pada hukum yang paling utama, yakni "Kasihanilah Tuhan Allahmu dengan segenap hatimu dan segenap jiwamu dan dengan segenap, hal budimu dan dengan segenap kekuatanmu dan kasihanilah sesama manusia seperti dirimu sendiri. Isi deklarasi di atas menggambarkan bagaimana bahwa pada dasamya manusia itu memiliki hak yang sama, tidak boleh membeda-bedakannya mesti mereka berlainan agama. Sikap saling hormatmenghormati agar kehidupan menjadi rukun sangat dianjurkan.

\section{Kerukanan Umat Dalam Perspektif Agama Budha}

Untuk membina dan memupuk sikap hidup rukun, sang Buddha menganjurkan "terdapat enam Dharma yang bertujuan agar kita saling mengingat, saling mencintai, saling menghormati, saling menolong, saling menghindari percekcokan, yang akan menunjang kerukunan persatuan dan kesatuan. Ajaran agama Buddha yang bersumber dari Sang Buddha bersifat inklusif dan terbuka dengan metode "ehipassiko" yang berarti "datang lihat dan buktikan", buka berdasar pada kepercayaan yang membabi buta, tetapi dengan keyakinan yang telah dibuktikan. (Timur et al., 2017).

Dalam Khuddhaka Nikaya, Khuddhaka Patha, Dhammapada 183 disebutkan Sabbapapasaa-karanang, Kusalasaupasampada, Saccitaparoyodapang (Terjemahan: tidak melakukan kejahatan, perbanyak berbuat kebajikan, serta sucikan hati dan pikiran). (Timur et al., 2017). Kepedulian terhadap lingkungan sosial merupakan salah satu wujud dari keimanan Buddhisme. Membangun sosial kemasyarakatan merupakan salah satu cita-cita kesejahteraan manusia, yang pada akhirnya dapat membawa kesejahteraan bagi negara dan bangsa. Selain itu, dalam perspektif agama Buddha, satu adalah semua dan semua adalah satu. Apapun yang dilakukan oleh seseorang baik atau buruk, akan dapat mempengaruhi masyarakat dan alam sekitar, karena semuanya adalah satu keseluruhan. Oleh karena itu, jika seseorang menginginkan kebahagiaan hidup, maka sesungguh-nya itu bukanlah untuk dirinya sendiri, melainkan secara bersama-sama untuk seluruh masyarakat, bersama-sama dalam kebahagiaan atau penderitaan, karena alam semesta terikat pada hukum ketergantungan.

Dari penjelasan di atas dapat dianalisa bahwa dalam perspektif agama Buddha, jika seseorang berbuat kejahatan, misalnya dengan mencela orang lain, atau agama orang lain maka sesungguhnya perbuatan tersebut justru amat merugikan agamanya sendiri. Oleh karena itu, kerukunan dan tolerasnis yang dianjurkan Sang Buddha adalah dalam pengertian bahwa semua orang hendaknya mau mendengar dan bersedia mendengarkan ajaran yang dianut orang lain (saling hormat menghormati).

\section{Kerukunan Umat Dalam Perspektif Agama Konghucu}

Agama Khonghucu termasuk agama yang baru diterima oleh bangsa Indonesia. Agama ini mengajarkan tentang toleransi yang sebenarnya yang menjadi prinsip dasar dari ajaran Khongucu adalah "Jangan lalukan [kepada orang lain] apa yang tidak ingin engkau terima diperlakukan oleh orang lain" [Tengah Sempurna, XII: 3].(Kerukunan Dalam Perspektif Agama-Agama Di Indonesia | Aqlania, n.d.).

Di samping itu, Nabi Khonghucu menyatakan bahwa "Seorang budiman berhati longgar dan lapang, seorang rendah budi berhati sempit dan berbelit-belit” [Sabda Suci, VII: 37]. Kemudian Nabi Khonghucu menegaskan dengan sabdanya "Seorang budiman menjunjung tiga syarat di dalam jalan suci. Di dalam sikap dan lakunya, ia menjaubkan sikap congkak dan angkuh, pada wajahnya selalu menunjukean sikap dapat dipercaya dan di dalam percakapan selalu ramah serta menjaubi kata-kata kasar” [Sabda Suci, VIII: 43]. Dan “di tempat penjuru lautan, 
semuanya bersaudara" [Sabda Suci, XII: 5]. (Kerukunan Dalam Perspektif Agama-Agama Di Indonesia | Aqlania, n.d.)

Berdasarkan beberapa penjelasan ajaran agama umat beragama tersebut di atas, maka jelas dan terang bahwa semua ajaran agama mendukung tegaknya kerukunan interen umat beragama, kerukunan antarumat beragama, dan kerukunan antara umat beragama dengan pemerintah. Sebetulnya tidak sulit, sebab setiap ajaran agama pasti mengajarkan penganutnya untuk hidup rukun baik terhadap sesama umat beragama maupun terhadap semua umat beragama, dengan kata lain kalau kita sungguh-sungguh taat pada ajaran yang telah diajarkan pada agama kita masing-masing.

Memang benar, kalau kita memahami secara seksama isi kandungan kitab suci kita masingmasing, maka secara otomatis kerukunan itu akan menjelma dalam kehidupan umat beragama. Begitu sebaliknya, jika kita tidak dapat memahami secara baik dan benar isi kandungan kitab suci kita masingamsing, maka secara otomatis akan menimbulkan ketidakrukunan dan menimbulkan konflik serta salah faham sehingga memunculkan ketidak toleransian dalam beragama. Walau bagaimana pun, kerukunan telah memberikan kontribusi kepada para tokoh agama, para ilmuwan, para penjabat dan masyarakat yang telah diperjuangkan untuk menjadi rukun dan damai di Republik Indonesia. Sebagaimana yang dipesankan oleh Presiden Republik Indonesia bahwa mengingat kemajemukan bangsa kita, maka saya dengan tidak jemu-jemunya mengingatkan agar kita semua, terutama para pemimpin bangsa kita, lebihlebih para pemuka agama, untuk memelihara kerukunan di antara kita. Berarti kerukunan umat beragama memang harus diperjuangkan karena tidak lepas dari intrik-intrik yang tidak senang terhadap kedamaian, ketenangan dan hidup rukun di bangsa Indonesia.

\section{KESIMPULAN}

Kerukunan umat dalam bingkai Negara Kesatuan Republik Indonesia tidak terlepas dari pentingnya pemahaman dan pengamalan bidang, kedudukan dan fungsi nilai-nilai pancasila, baik secara tersurat maupun secara tersirat. Karena jika nilai-nilai tersebut tidak dipahami secara mendalam, maka cita-cita dan tujuan kemenangan sebuah Negara Indonesia tidak akan terwujud. Pancasila telah menjadikan landasan dasar pijakan kita sebagai warganegara untuk saling bertaqwa kepada tuhan yang maha esa, hidup bersama tanpa diskriminasi, bersatu tanpa berpecah belah, bermusyawarah untuk mencapai mufakat dalam pengambilan keputusan serta bersikap dan berlaku adil bagi sesama. Bahkan dalam semua ajaran agama di Indonesia mengajarkan tentang nilai kebaikan, dan tidak ada satu ajaran agama manapun yang mengajarkan keburukan.

Atas dasar inilah kesepakatan para pendiri bangsa kita menempatkan nilai ketuhanan pada sila pertama, dengan cita-cita nilai-nilai pancasila tersebut dijiwai, diilhami dan dirasakan bagi seluruh umat dan/atau warga Negara Indonesia. Disamping itu menjadi sumber etika dan moral dalam membentuk jati diri generasi penerus bangsa Indonesia. 


\section{Referensi}

Kerukunan dalam Perspektif Agama-Agama di Indonesia | Aqlania. (n.d.). Retrieved July 10, 2020, from http://jurnal.uinbanten.ac.id/index.php/aqlania/article/view/1025

Memahami, U., Mengimplementasikan, D. A. N., Pancasila, N., Kehidupan, D., \& Octavian, W. A. (n.d.). Urgensi memahami dan mengimplementasikan nilai- nilai pancasila dalam kehidupan sehari-hari sebagai sebuah bangsa. 123-128.

Mahfud, dkk. 2012. "Kongres Pancasila IV: Strategi Pelembagaan Nilai-Nilai Pancasila dalam menegakean Konstitusionalitas Indonesia," Prosiding, Yogyakarta: PSP UGM. Hal.120

Prof. Suteki, Dosen Matkul Pancasila Yang Dicopot Dari Jabatan Kerena Berbeda Pendapat. (2020, June 2). https://www.youtube.com/watch?v=wEG029FENCA\&feature=youtu.be

Satrio dkk. 2017. Pendidikan Pancasila Untuk Perguruan Tinggi. Akademika. Hal.1

S.Fatimah,Ria.2010. Ilmu Pendidikan. Jakarta: PT Gramedia Pustaka Utama. Hal 28

Timur, J., Yudiana, I. K., Pardi, I. W., Asi, T., Karana, T. H., \& Patra, K. (2017). Masyarakat Multikultur Di Ujung Timur Pulau Jawa (Studi Kasus Di Desa Patoman, Blimbingsari ,. 6(2), 147-158.

Undang-Undang Nomor 20 Tahun 2003 Tentang Sistem Pendidikan Nasional

Undang-Undang Nomor 12 Tahun 2011 Tentang Pembentukan Peraturan Perundang-Undangan

Undang-Undang Nomor 12 Tahun 2012 Tentang Pendidikan Tinggi 